\title{
Upregulation of insulin-like growth factor I gene expression in the lesions of osteoarthritic human articular cartilage
}

\author{
James F S Middleton, Jenny A Tyler
}

\begin{abstract}
Expression of insulin-like growth factor I (IGF-I) mRNA and IGF-I protein was studied in human osteoarthritic and young articular cartilage by in situ hybridisation and immunohistochemistry. In situ hybridisation showed that relatively low amounts of IGF-I mRNA signal were present in anatomically normal regions of osteoarthritic and young cartilage. In fibrillated osteoarthritic cartilage, however, the signal intensity was significantly higher than in non-fibrillated cartilage. Particularly high levels of IGF-I mRNA were present in the surface cell clones of more advanced lesions, the amount of signal being about four to five times greater than in anatomically normal cartilage. The amount of message varied with cartilage depth. In young cartilage there was less IGF-I mRNA in the superficial zone than in the middle and deep zones. In fibrillated regions of osteoarthritic joints the amount of message in surface cells was greater than in deeper regions. A specific human IGF-I antibody was used to show the presence intracellularly of IGF-I protein in osteoarthritic and young cartilage.

Raised levels of IGF-I message in osteoarthritic chondrocytes may represent an attempt at increased matrix repair, operating by an autocrine/paracrine mechanism.
\end{abstract}

Articular cartilage consists of chondrocytes embedded in an extensive extracellular matrix. In normal tissue the chondrocytes actively effect a stable equilibrium between the synthesis and degradation of matrix components, so that a constant concentration of these components is maintained. In degenerative joint disease, such as osteoarthritis, the stable equilibrium is disrupted and the rate of loss of proteoglycan from the matrix eventually exceeds the rate of deposition of newly synthesised molecules. ${ }^{12}$ It is of interest, therefore, to understand the influence of growth factors on this equilibrium.

Insulin-like growth factors (IGFs) or somatomedins are polypeptides with structural and functional homology to proinsulin. ${ }^{3}$ In man, two major IGFs, IGF-I (somatomedin C) and IGF-II, have been characterised by amino acid sequence analysis of peptides purified from serum $^{45}$ and by isolation of cDNAs encoding precursor forms of IGFs. ${ }^{6} 7$ Insulin-like growth factors play a part in the growth and development of many tissues during fetal and adult life, ${ }^{3} 8$ and are implicated in tissue hypertrophy and repair. ${ }^{9}$ Insulin-like growth factor I is known to enhance matrix synthesis in normal cartilage in vivo ${ }^{10}$ and in vitro. ${ }^{11} 12$ In addition, specific IGF-I receptors have been demonstrated on rabbit and bovine articular chondrocytes. ${ }^{13} 14$

Traditionally, IGF-I was considered to be produced primarily in the liver in response to a systemic signal and transported by the circulation to act on target tissues at distant sites (endocrine function). ${ }^{15}$ There is now evidence, however, that IGF-I is synthesised by cells of mesenchymal origin in many different tissues. Immunoreactive IGF-I protein has been detected in extracts of human ${ }^{16}$ and rat organs. ${ }^{17}$ mRNA encoding IGF-I can be detected in a number of fetal and adult rat tissues ${ }^{18}$ and human fetal tissues. ${ }^{19}$ The concentrations of immunoreactive IGF-II and abundance of IGF-I mRNA are regulated by growth hormone in a variety of adult rat organs. ${ }^{17} 20$ Insulin-like growth factor I is secreted by cultured explants of rodent tissues $^{21} 22$ and by monolayers of human fibroblasts and osteoblast-like cells. ${ }^{23}{ }^{24}$ These data suggest that IGFs can act locally by autocrine or paracrine mechanisms, or both.

The aim of our study was to determine whether the IGF-I gene is expressed by human articular chondrocytes. We asked the questions: Does articular cartilage have the potential to synthesise a growth factor that may be involved in matrix repair? Could chondrocytes respond to progressive matrix loss, as occurs in osteoarthritis, by producing more growth factor?

\section{Materials and methods}

TISSUE SOURCE AND PREPARATION

Twenty six blocks of osteoarthritic femoral articular cartilage were taken from seven subjects, aged 64-77 years, at total joint replacement operations. Osteoarthritic blocks were sampled from the superior surface of femoral heads adjoining regions of total cartilage loss and from the inferior surface that was macroscopically intact. Nine anatomically normal samples from the weightbearing regions of femoral articular cartilage were obtained from young subjects, aged 12-24 years, at osteosarcoma operations. Blocks were embedded in Tissue Tek II OCT compound (Miles Laboratories, Naparavill, IL, USA), frozen in liquid nitrogen, and stored at $-70^{\circ} \mathrm{C}$. The time between surgical operation and freezing of the tissue was not more than six hours.

PREPARATION OF PROBES

In situ hybridisation was performed using in vitro synthesised RNA labelled with $\left[{ }^{35}\right.$ S] uridine triphosphate. Human cDNA encoding IGF-I was developed by Jansen et $a l^{6}$ (Department of 
Paediatrics, State University of Utrecht, the Netherlands). This sequence encodes the entire IGF-I precursor, and is complementary to human IGF-I mRNA on northern blots with multiple transcript sizes of $0 \cdot 7,5 \cdot 3$, and $8 \cdot 0$ kilobases. ${ }^{25}$ Insulin-like growth factor I cDNA (560 base pairs) was subcloned in opposite orientations into pSP64 and pSP65 vectors (Promega Biotec, Madison, WI, USA). After linearisation of the plasmids, antisense and control sense ${ }^{35} S$ labelled RNA transcripts were synthesised using SP6 promoters. The template DNA was removed by RNase-free DNase I (Pharmacia, Freiburg, FRG), and the probes were purified by centrifugation chromatography
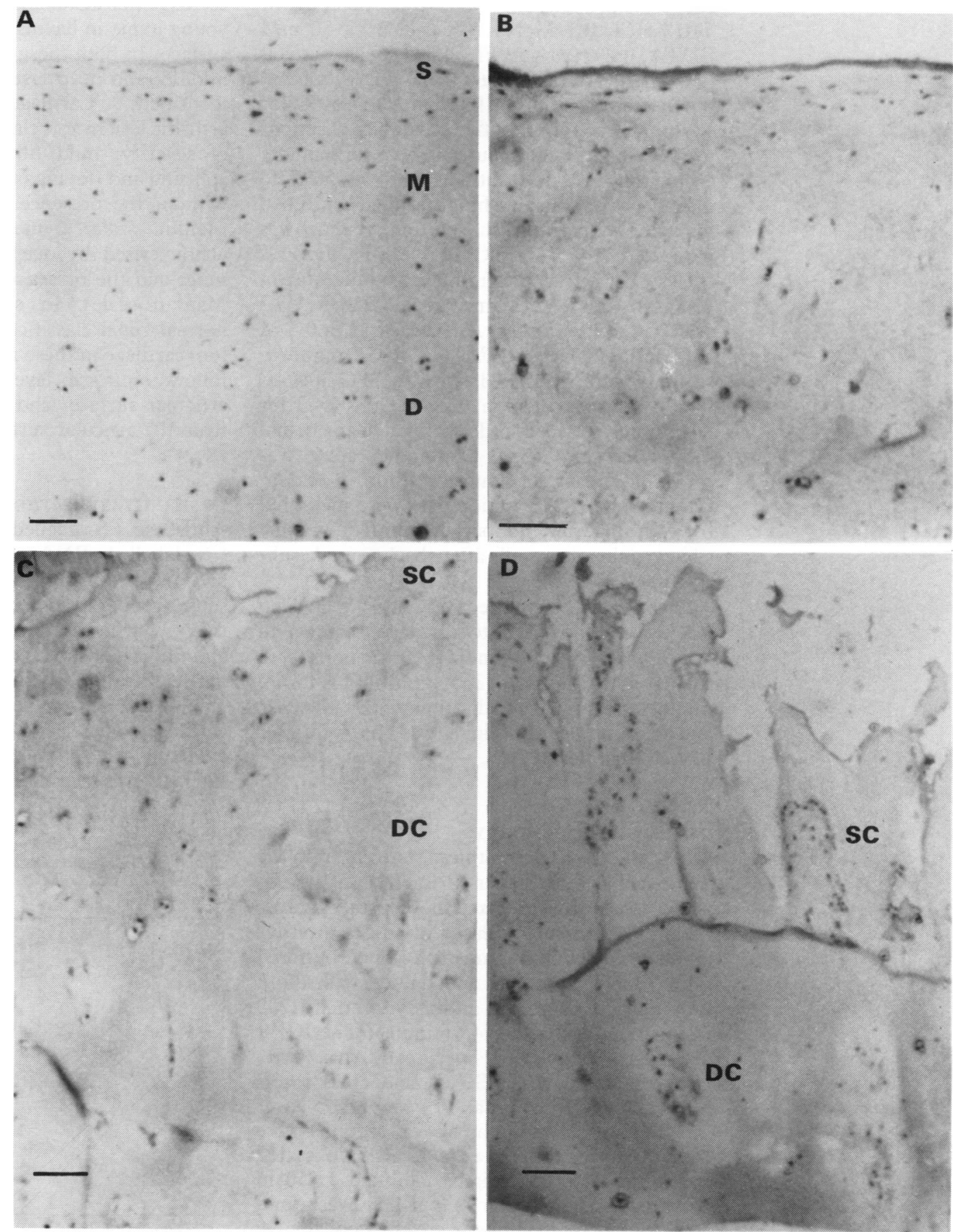

(Sephadex-G50; Pharmacia). ${ }^{26}$ Full length transcripts were degraded to 50-150 bases by limited alkaline hydrolysis $(40 \mathrm{mM} \mathrm{NaHCO} 3$, $60 \mathrm{mM} \mathrm{Na} \mathrm{CO}_{3}(\mathrm{pH} \mathrm{10} 2), 75$ minutes, $60^{\circ} \mathrm{C}$ ) for optimal hybridisation efficiency. ${ }^{27}$

\section{IN SITU HYBRIDISATION}

These procedures were modifications of protocols described by Brahic and Haase,${ }^{28} \mathrm{Cox}$ et $a l,{ }^{27}$ and Funa et al. ${ }^{29}$ Cryostat sections, $6 \mu \mathrm{m}$ thick, were cut at $-40^{\circ} \mathrm{C}$ and thaw mounted onto slides treated with 3-aminopropyltriethoxysilane, prepared as described by Tourtellotte $e t$ al. ${ }^{30}$ Sections were fixed in

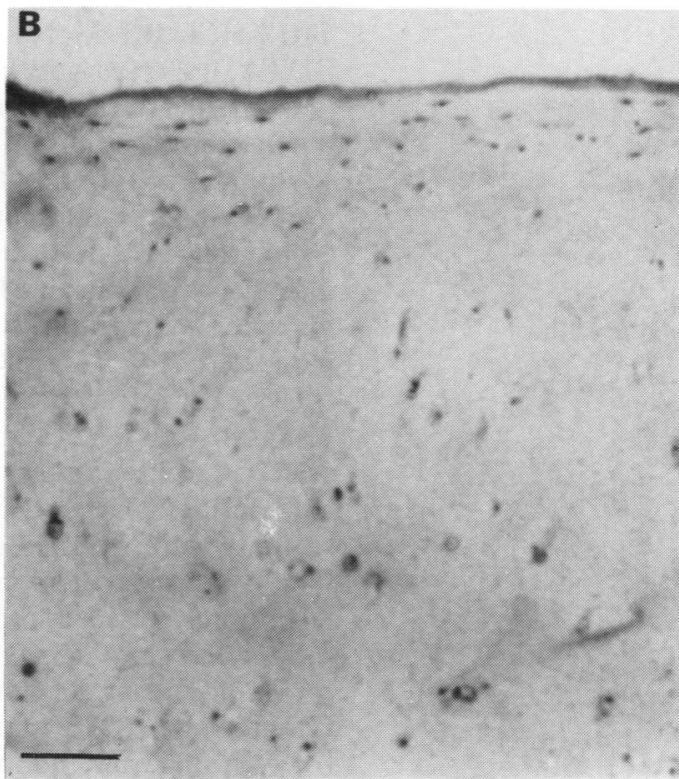

Figure 1 Representative low magnification photomicrographs of human articular cartilage. (A) Cartilage from young subjects showing a smooth intact articular surface. $S=$ superficial layer; $M=$ middle layer; $D=$ deep layer. $(B)$ Cartilage from macroscopically intact regions of osteoarthritic joints has the same anatomical features as $A$. (C) Mild fibrillation from an osteoarthritic joint with surface dissuption. $(D)$ More advanced fibrillation characterised by deeper clefts and cell clones. $S C=$ surface cells $(<150 \mu \mathrm{m}$ deep $) ; D C=$ deeper cells $(>150 \mu \mathrm{m}$ deep $)$. Haematoxylin and eosin. Bar $=100 \mu \mathrm{m}$. 
4\% paraformaldehyde, permeabilised in $0 \cdot 1 \%$ Triton X-100, and dehydrated in a graded alcohol series. Slides were then air dried and stored at $4^{\circ} \mathrm{C}$ until used. Tissue sections were treated with $0.2 \mathrm{M} \mathrm{HCl}$ for 20 minutes to remove basic proteins, and acetylated for 10 minutes in freshly prepared $0.1 \mathrm{M}$ triethanolamine ( $\mathrm{pH} 8 \cdot 0$ ) containing $0.25 \%$ ( $\mathrm{vol} / \mathrm{vol}$ ) acetic anhydride. Sections were dehydrated in an ethanol series and air dried. ${ }^{35} \mathrm{~S}$ labelled RNA was heated to $80^{\circ} \mathrm{C}$ for 30 seconds then cooled on ice, and hybridisation was performed under siliconised glass coverslips in $40 \%$ formamide, $10 \%$ (wt/vol) dextran sulphate, 200 $\mu \mathrm{g}$ total yeast $\mathrm{RNA} / \mathrm{ml}, 8 \mathrm{mM}$ dithiothreitol, ${ }^{35} \mathrm{~S}$ labelled RNA $\left(3.5 \times 10^{6} \mathrm{cpm} / \mathrm{section}\right.$ for antisense and sense probes), and 'salts' ( $3 \mathrm{M} \mathrm{NaCl}, 0.1 \mathrm{M}$ TRIS-HCl, $0 \cdot 1 \mathrm{M} \mathrm{Na}_{3} \mathrm{PO}_{4}$ (pH 6.8), $50 \mathrm{mM}$ EDTA, 0.2\% (wt/vol) Ficoll 400, 0.2\% (wt/vol) polyvinylpyrrolidone $360000,0.2 \%$ (wt/vol) bovine serum albumin fraction $\mathrm{V}$ ) at $50^{\circ} \mathrm{C}$ for 18 hours in a humidified chamber. Sections were washed for 60 minutes in $50 \%$ formamide, 'salts', and $10 \mathrm{mM}$ dithiothreitol at $50^{\circ} \mathrm{C}$ to dislodge coverslips; washing was then continued for two hours in fresh solution. Tissue was incubated in $0.5 \mathrm{M} \mathrm{NaCl}$ in TRIS-HCl/EDTA $\left(\mathrm{pH} \mathrm{7.6)}\right.$ at $37^{\circ} \mathrm{C}$ for 15 minutes and digested in $20 \mu \mathrm{g} / \mathrm{ml}$ RNase A (Sigma, Poole, Dorset, UK) at $37^{\circ} \mathrm{C}$ for 30 minutes. After washing in $0.5 \mathrm{M}$ $\mathrm{NaCl}$ in TRIS-HCl/EDTA $\left(37^{\circ} \mathrm{C}\right.$ for 30 minutes), sections were incubated twice in SSC at $45^{\circ} \mathrm{C}$ for 30 minutes then in $0.2 \times S S C$ at $45^{\circ} \mathrm{C}$ for 30 minutes. Tissue was dehydrated in an ethanol series and air dried. Autoradiography was for 21 days using $\mathrm{K} 5$ emulsion (Ilford, London, UK). In situ hybridisation data were measured by counting the number of autoradiographic silver grains per cell after background subtraction.

Two controls were used: (a) sense ${ }^{35} \mathrm{~S}$ labelled RNA was hybridised to cartilage sections to indicate non-specific binding; $(b)$ sections were treated with RNase A $(200 \mu \mathrm{g} / \mathrm{ml}$ in TE for 30 minutes) before hybridisation with antisense and sense probes. No signal was observed after RNase treatment.

\section{IMMUNOHISTOCHEMISTRY}

Cryostat sections ( $6 \mu \mathrm{m}$ thick) were cut from the same cartilage as that used for in situ hybridisation. Sections were fixed in $4 \%$ paraformaldehyde for 30 minutes, placed in blocking buffer ( $1 \%$ bovine serum albumin in phosphate buffered saline) for 15 minutes, and treated with $25 \mu \mathrm{l}$ rabbit antihuman IGF-I antibody (diluted 1:200 in blocking buffer) for 45 minutes. The IGF-I antibody binds IGF-I specifically, has $0.5 \%$ cross reactivity with IGF-II, and cross reacts minimally with insulin at $10^{-6} \mathrm{~mol} / \mathrm{l}^{31} 32 \mathrm{After}$ washing and blocking as above, sections were incubated for 30 minutes in $25 \mu$ l biotinylated goat antirabbit IgG (Sigma), diluted 1:250 in blocking buffer. After a further wash and blocking step, sections were treated for 30 minutes with $2.5 \mu \mathrm{g} / \mathrm{ml}$ streptavidin-peroxidase (Sigma) in $0.1 \mathrm{M}$ TRIS-HCl (pH 7.6) containing $1 \%$ bovine serum albumin. The sections were washed with $0 \cdot 1 \mathrm{M}$ TRIS-HCl, $\mathrm{pH} 7 \cdot 6$, for two minutes and then treated with substrate $(0.5 \mathrm{mg} / \mathrm{ml}$ diaminobenzidine in TRIS- $\mathrm{HCl}$ and $0.01 \% \mathrm{H}_{2} \mathrm{O}_{2}$ ) for 15 minutes. After a final wash with TRIS-HCl followed by distilled water, sections were mounted in Apathy's medium and viewed by Nomarski interference microscopy.

\section{Results}

TISSUE SAMPLING

Figure 1 shows low magnification photomicrographs of representative cartilage samples, indicating the type of tissue used for this study. Articular cartilage from macroscopically normal regions of osteoarthritic joints served as controls to cartilage from osteoarthritic lesions. This cartilage was histologically similar to tissue from young joints in having a smooth intact articular surface. In both these cartilages the superficial, middle, and deep layers (or zones) were easily identified. ${ }^{33}$ Cartilage sampled from osteoarthritic lesions was classified into two categories of severity: mild fibrillation with superficial splitting and fraying of the articular surface, yet without the presence of cell clones ( 4 on the Mankin scale $^{34}$ ); more advanced fibrillation characterised by deeper clefts, cartilage thinning, and the presence of cell clones ( 8 on the Mankin scale). In osteoarthritic lesions the normal zonal classification is disrupted; therefore cartilage in these regions was categorised as follows: surface layer, $<150 \mu \mathrm{m}$ from the articular surface, and deeper layer, $>150 \mu \mathrm{m}$ from the articular surface.

\section{IN SITU HYBRIDISATION}

Antisense ${ }^{35} \mathrm{~S}$ labelled RNA probes and sense ${ }^{35} \mathrm{~S}$ labelled RNA probes were applied to sections of human articular cartilage. The antisense probe hybridises specifically to IGF-I mRNA, whereas the sense probe is a control and indicates non-specific binding. With the antisense probe, IGF-I mRNA was detected in chondrocytes from osteoarthritic and young cartilage, whereas only a minimal signal was evident with the sense probe (fig 2). Signal intensity was measured by counting the number

Table I Background measurements over cartilage matrix

\begin{tabular}{|c|c|c|}
\hline Cartilage layer* & Antisense & Sense \\
\hline $\begin{array}{l}\text { A } \\
\text { Superficial } \\
\text { Middle } \\
\text { Deep }\end{array}$ & $\begin{array}{l}2(0 \cdot 2) \dagger \\
2(0 \cdot 2) \\
1(0 \cdot 1)\end{array}$ & $\begin{array}{l}2(0 \cdot 3) \\
1(0 \cdot 2) \\
1(0 \cdot 2)\end{array}$ \\
\hline $\begin{array}{l}\text { B } \\
\text { Superficial } \\
\text { Middle } \\
\text { Deep }\end{array}$ & $\begin{array}{l}2(0 \cdot 1) \\
1(0 \cdot 2) \\
3(0 \cdot 2)\end{array}$ & $\begin{array}{l}3(0 \cdot 2) \\
2(0 \cdot 3) \\
2(0 \cdot 3)\end{array}$ \\
\hline $\begin{array}{l}\text { C } \\
\text { Surface } \\
\text { Deep }\end{array}$ & $\begin{array}{l}2(0 \cdot 3) \\
2(0 \cdot 2)\end{array}$ & $\begin{array}{l}1(0 \cdot 3) \\
1(0 \cdot 2)\end{array}$ \\
\hline $\begin{array}{l}\text { D } \\
\text { Surface } \\
\text { Deep }\end{array}$ & $\begin{array}{l}4(0 \cdot 4) \\
4(0 \cdot 3)\end{array}$ & $\begin{array}{ll}3 & (0 \cdot 3) \\
6 & (0 \cdot 4)\end{array}$ \\
\hline
\end{tabular}

${ }^{*} A=$ young normal cartilage; $B=$ anatomically normal cartilage from osteoarthritic joints; $\mathrm{C}=$ mildly fibrillated cartilage from osteoarthritic join

arthritic joints.

tAll values represent means (SE) and indicate number of grain per $80 \mu \mathrm{m}^{2}$, the average area of a human chondrocyte on a histological section. Total area sampled per value $=3500 \mu \mathrm{m}^{2}$. 
of autoradiographic silver grains overlying a cell after background subtraction. Table 1 gives background measurements for the different cartilage samples. Chondrocytes were scored positive for IGF-I message when the signal intensity using the antisense probe was greater than that using the sense probe. A high proportion of osteoarthritic and young chondrocytes, between 70 and $100 \%$, were positive for IGF-I mRNA, as shown in table 2.

The amount of IGF-I message in chondrocytes was estimated (fig 3 ). In young cartilage the

IGF-I mRNA signal intensity was relatively low and did not differ from anatomically normal cartilage from osteoarthritic joints. In fibrillated osteoarthritic cartilage the signal intensity was significantly higher than in anatomically normal cartilage. There were only slightly more silver grains/cell in more advanced lesions than in mild lesions, and this difference was not significant.

Several differences in signal intensity were apparent when data were expressed as variation with cartilage depth (fig 4). In young cartilage
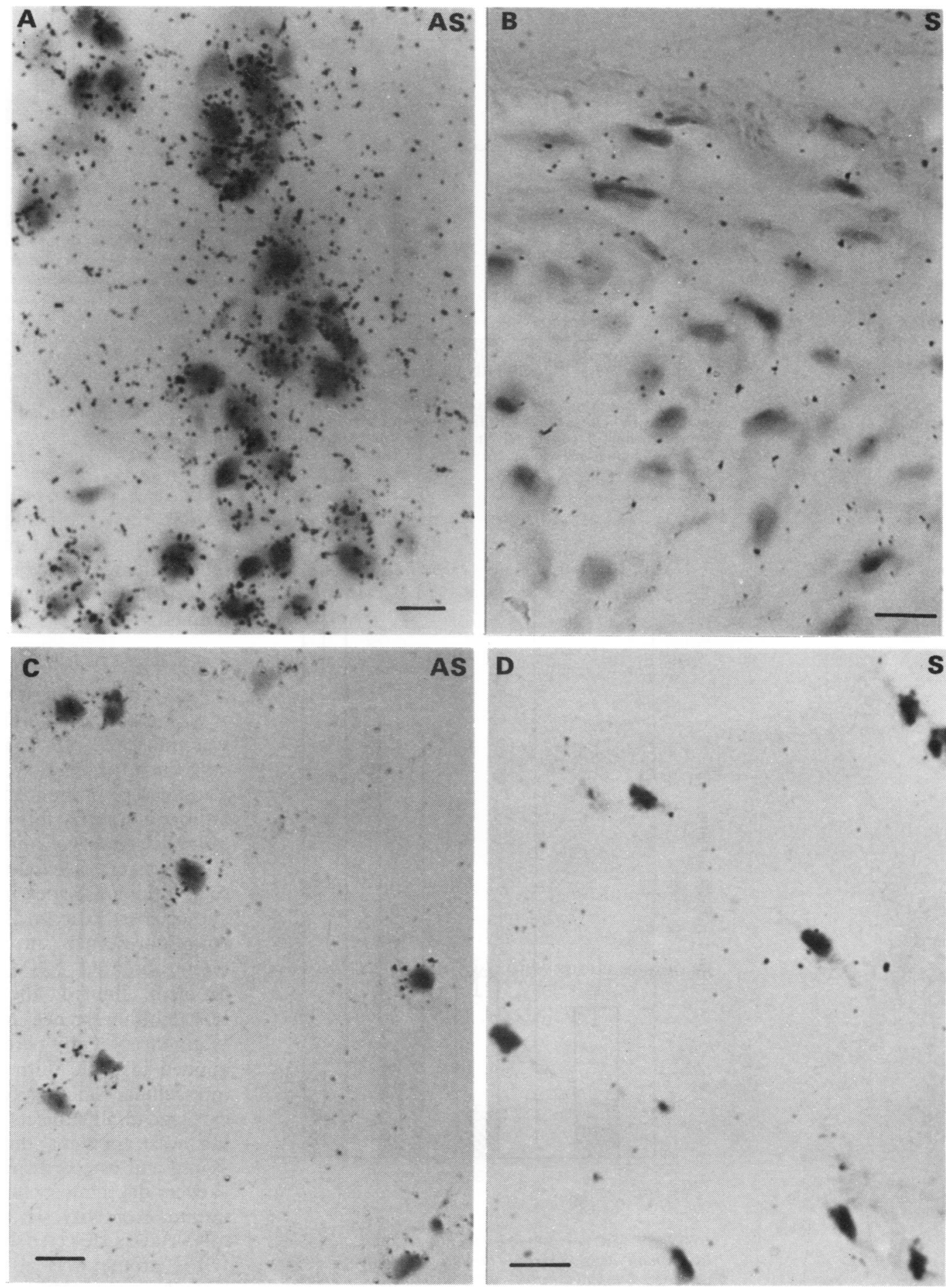

Figure 2 Photomicrographs of in situ hybridisation of insulin-like growth factor I (IGF-I) mRNA in human articular cartilage using ${ }^{35} S$ labelled antisense $(A S)$ and sense $(S) R N A$ probes. With the antisense probe IGF-I message is present in most chondrocytes, whereas with the control sense probe there is minimal signal over cells. (A and B) Cell clones from more advanced lesions of osteoarthritic cartilage (see fig $1 D$ for low magnification histology). (C and D) Chondrocytes from anatomically normal young cartilage (see fig IA for low magnification histology). Haematoxylin and eosin. Bar=10 $\mu m$. 
there were less grains/cell in the superficial layer than in the middle and deep layers. Anatomically normal cartilage of osteoarthritic joints differed from young cartilage with significantly more signal in the middle layer than in superficial and deep layers. In both mild and more advanced fibrillation the number of grains/cell was significantly higher in surface cells than in deeper cells. There was a particularly high signal

Table 2 Percentages of chondrocytes containing insulin-like growth factor I (IGF-I) message

\begin{tabular}{llc}
\hline Cartilage layer & $\begin{array}{l}\text { Cells } \\
\text { examined }(n)\end{array}$ & $\begin{array}{l}\text { Chondrocytes containing } \\
\text { IGF-I message (\%) }\end{array}$ \\
\hline A & 60 & 73 \\
Superficial & 60 & 85 \\
Middle & 60 & 88 \\
Deep & & \\
B & 15 & 80 \\
Superficial & 15 & 100 \\
Middle & 15 & 93 \\
Deep & & \\
C & 15 & 100 \\
Surface & 15 & 90 \\
Deep & & \\
D & 66 & 97 \\
Surface & 66 & 72 \\
Deep & &
\end{tabular}

Cells were scored positive for IGF-I mRNA when the signal using the antisense ${ }^{35} S$ labelled RNA probe was greater than that using the control sense probe.

$\mathrm{A}=$ young cartilage; $\mathrm{B}=$ anatomically normal cartilage from osteoarthritic joints; $\mathrm{C}=$ mildly fibrillated cartilage from osteo arthritic joints; $\mathrm{D}=$ more advanced lesion from osteoarthritic joints containing cell clones. In $C$ and $D$, surface $=<150 \mu \mathrm{m}$ deep $=>150 \mu \mathrm{m}$.

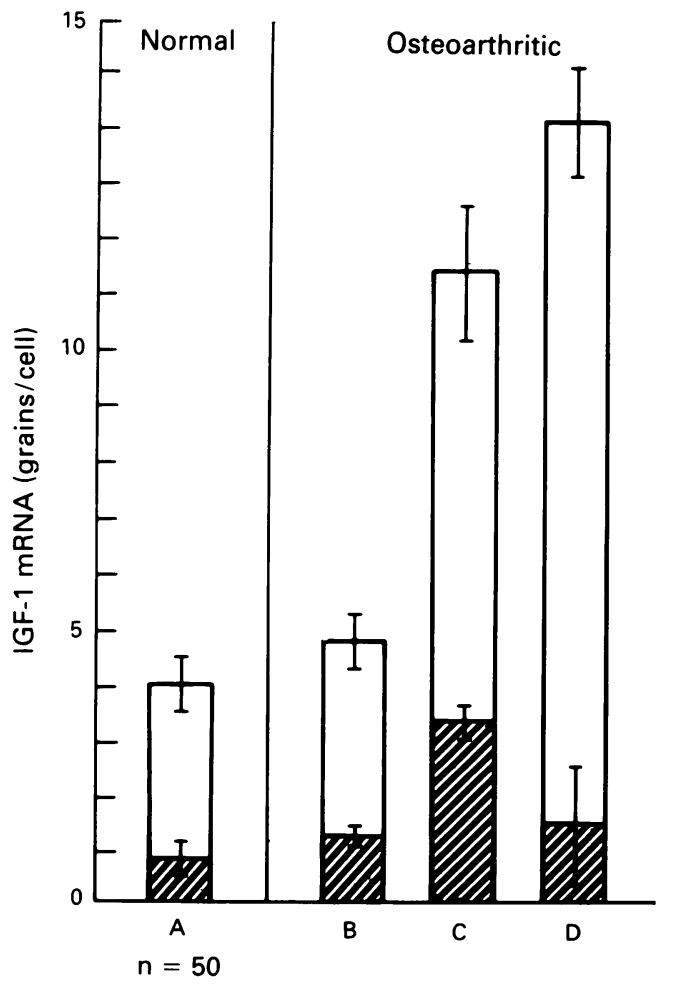

Figure 3 Measurement of in situ hybridisation of insulinlike growth factor I (IGF-I) mRNA in human articular
cartilage. Unshaded values are results using ${ }^{35}$ S labelled antisense RNA probes and shaded values using ${ }^{35} S$ labelled control sense RNA probes. (A) Anatomically normal young cartilage; $(B)$ anatomically normal cartilage from osteoarthritic joints; $(C)$ mild fibrillation from osteoarthritic joints; $(D)$ more advanced fibrillation with cell clones from osteoarthritic joints (see fig l for histology).

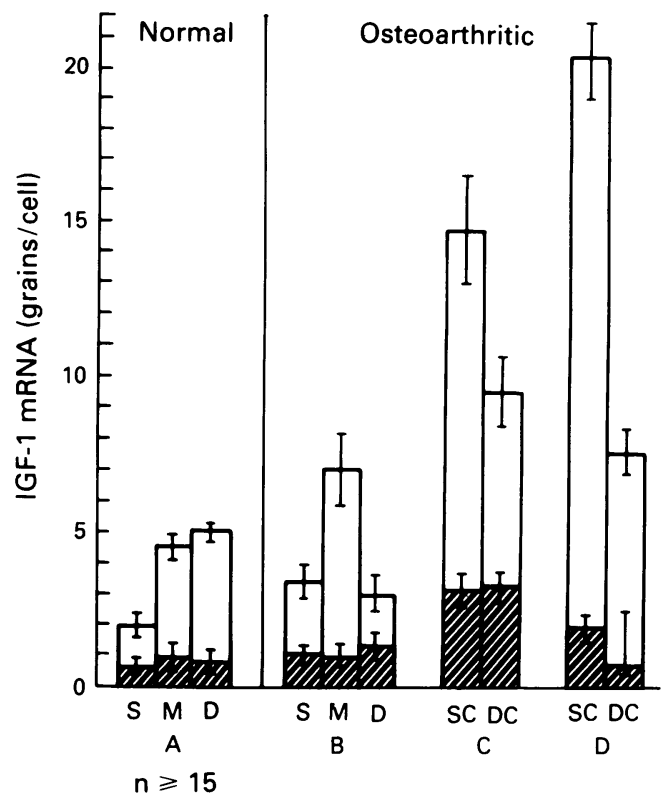

Figure 4 Measurement of in situ hybridisation of insulin-like growth factor I (IGF-I) mRNA in human articular cartilage. Variation with cartilage depth. Unshaded values are results using ${ }^{35} S$ labelled antisense $R N A$ probes and shaded values using ${ }^{35} S$ labelled control sense RNA probes. (A) Anatomically normal cartilage; $(B)$ anatomically normal cartilage from osteoarthritic joints; (C) mild fibrillation from osteoarthritic joints; $(D)$ more advanced fibrillation with cell clones from osteoarthritic joints. $S=$ surface layer; $M=$ middle layer; $D=$ deep layer; $S C=$ surface cells; $D C=$ deep cells (see fig 1 for histology).

intensity in surface cell clones of more advanced lesions, the levels being about four to five times higher than in anatomically normal cartilage. These changes were evident in the lesions of osteoarthritic cartilage from all the subjects studied.

\section{IMMUNOHISTOCHEMISTRY}

It was important to establish that IGF-I mRNA was translated into protein. Therefore sections adjacent to those processed for in situ hybridisation were immunolabelled with a polyclonal antibody specific for IGF-I. ${ }^{31} 32$ Initially, immunofluorescence microscopy was used and a cytoplasmic distribution of IGF-I protein was seen in chondrocytes from all depths of young and osteoarthritic cartilage (results not shown). Autofluorescence in osteoarthritic cartilage often obscured IGF-I fluorescence and this problem limited the effectiveness of the immunofluorescence technique. Therefore, a biotin-streptavidin-peroxidase technique was applied instead. With this method an intense intracellular staining reaction was seen in the cartilage of all subjects examined (fig 5). Staining was apparent throughout the depth of young and osteoarthritic articular cartilage and at every depth most chondrocytes showed IGF-I immunoreactivity. In all regions where IGF-I mRNA was detected by in situ hybridisation, IGF-I protein was also detected by immunohistochemistry. Although it was not possible to measure the amount of IGF-I protein in chondrocytes, qualitative examination indicated particularly intense staining reactions in cell clones of more advanced osteoarthritic lesions. 

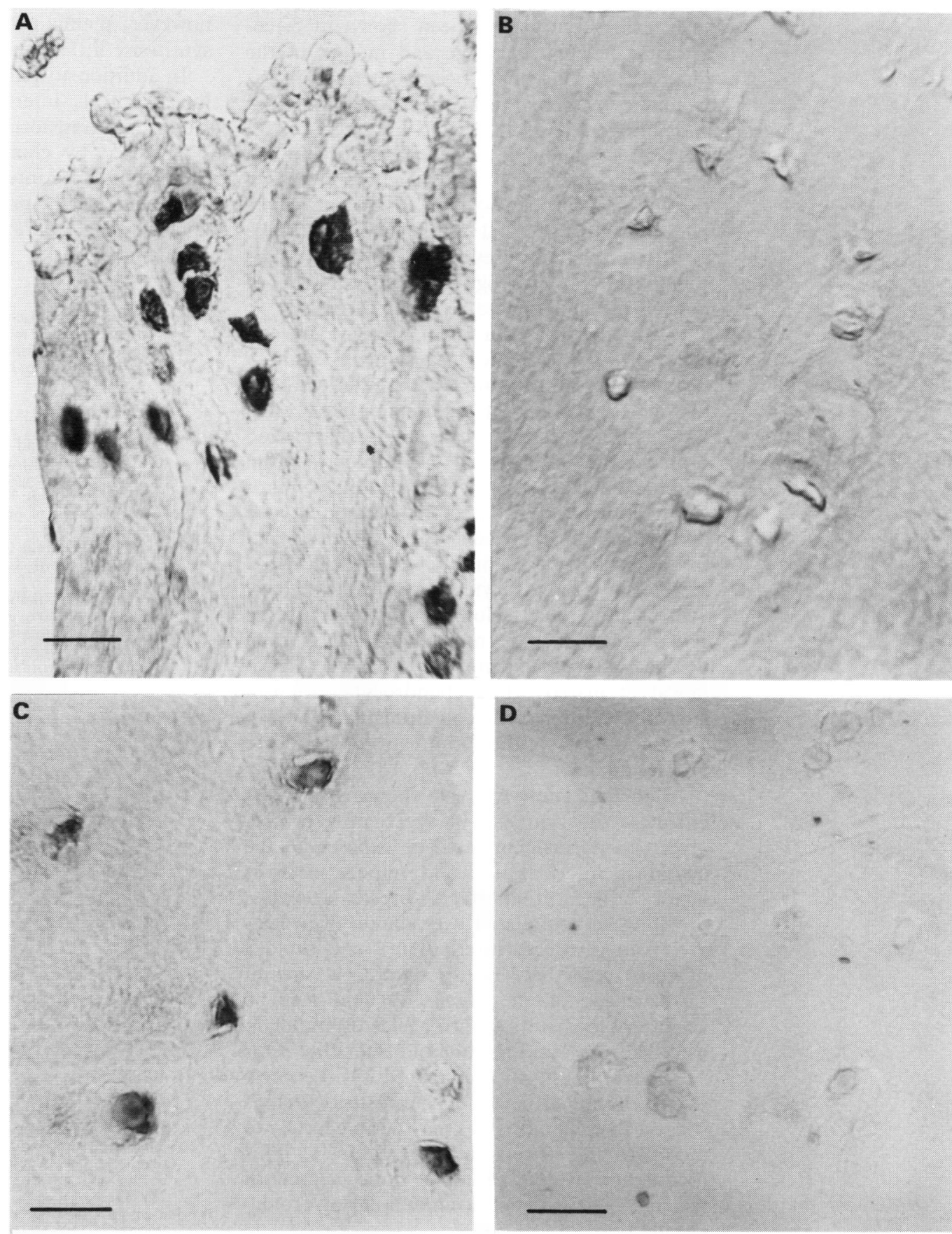

Figure 5 Immunohistochemical localisation of insulin-like growth factor $I(I G F-I)$ protein in human articular cartilage, showing IGF-I distributed intracellularly in a cluster of chondrocytes close to the articular surface of an osteoarthritic lesion $(A)$ and in mid-zone chondrocytes of an anatomically normal region of osteoarthritic cartilage $(C) .(B)$ and $(D)$ are controls, in the absence of primary antibody, of cells from an osteoarthritic lesion and from anatomically normal osteoarthritic cartilage respectively. Nomarski interference microscopy. Bar $=20 \mu \mathrm{m}$.

Staining was absent in control experiments where the primary antibody was omitted.

\section{Discussion}

Our study shows relatively low levels of IGF-I message in anatomically normal osteoarthritic cartilage. In fibrillated osteoarthritic cartilage, however, the message levels were increased and were proportional to the severity of the lesion. This upregulation in osteoarthritic lesions probably represents an attempt at increased matrix replacement and reflects the local mechanical and biochemical demands made by the microenvironment on the chondrocytes.
Thus the particularly high levels of IGF-I mRNA in surface cell clones may indicate a situation where matrix loss is most acute and the demand for matrix repair highest. Our results are in accord with studies on kidney and skeletal muscle, where locally produced IGF-I may also be particularly important in hypertrophy and repair. ${ }^{8}$

Increased synthesis of IGF-I at osteoarthritic lesions may lead to one or more of the following effects: stimulation of proteoglycan production, decreased degradation of proteoglycan, stimulation of collagen production, and increased chondrocyte replication. Increased proteoglycan and collagen production and enhanced 
mitogenic activity have been shown in osteoarthritic articular cartilage and models of the disease. ${ }^{34-36}$ There have been numerous studies in animal systems showing the matrix promoting and mitogenic effects of IGF-I, but there is a lack of information on osteoarthritic human articular cartilage. It has long been known that IGFs could stimulate $\left[{ }^{35} S\right]$ sulphate incorporation into rat costal cartilage. ${ }^{37}$ Insulin-like growth factor I increases synthesis and decreases catabolism of proteoglycans in cultures of normal pig and bovine articular cartilage. ${ }^{38} 39$ The growth factor is a major mediator in fetal calf serum $^{12}$ and human synovial fluid, ${ }^{40}$ responsible for increasing proteoglycan synthesis in bovine cartilage explants. Insulin-like growth factor I increases the synthesis of collagen and proteoglycan in cultured chondrocytes from rabbit articular cartilage. ${ }^{11}{ }^{41}$ In addition, mitogenic actions of IGF-I are demonstrated in vitro by normal human articular chondrocytes, ${ }^{42}$ and by rabbit articular chondrocytes, where IGF-I secreted by chondrocytes may stimulate their own proliferation. ${ }^{43}$ However, these mitogenic actions of IGF-I are not apparent in normal bovine cartilage explants. ${ }^{38}$ Possibly, the removal of matrix when chondrocytes are isolated for culture results in upregulated IGF-I production, which then stimulates chondrocyte proliferation.

In another study we have shown that IGF-I enhances the synthesis of aggregating proteoglycan in normal pig cartilage exposed to the cytokines interleukin 1 and tumour necrosis factor. ${ }^{39}$ In addition, IGF-I directly decreases the cytokine stimulated degradation of proteoglycan in cartilage. Interleukin 1 and tumour necrosis factor have been identified at sites of cartilage erosion in patients ${ }^{44}$ and may be important mediators of cartilage deterioration in osteoarthritis $^{46}$ and rheumatoid arthritis. ${ }^{47}$ Our present results showing enhanced IGF-I expression in the chondrocytes of osteoarthritic lesions suggest that chondrocytes may be able locally to modulate the actions of interleukin 1. This modulation would promote some degree of matrix repair and net accumulation of proteoglycan.

A high proportion of chondrocytes, about $70-100 \%$, contain IGF-I message, depending on cartilage source and tissue depth. These data support the concept of an autocrine/paracrine mode of action of IGF-I, acting locally on the same cell or nearby cells. Insulin-like growth factor I mRNA and immunoreactive IGF-I have also been demonstrated in epiphysial chondrocytes of the rat growth plate by in situ hybridisation and immunofluorescence microscopy ${ }^{48} 49$; these observations suggest that locally produced IGF-I has a specific role in the clonal expansion of differentiated epiphysial chondrocytes. Variable results have been reported for IGF-I production by chondrocytes in vitro, depending on the culture system used. Pelvic cartilage from chick embryos produces IGF-I peptides in serum free organ culture where cartilage growth is mediated by IGF-I. ${ }^{50}$ Rabbit articular chondrocytes synthesise IGF-I in serum free medium supplemented with fibroblast growth factor. ${ }^{43}$ Bovine articular cartilage explants, however, maintained in serum free conditions synthesise little or no IGF-I. ${ }^{38}$

In addition to IGF-I, evidence suggests that interleukin 1 , interleukin 6 , tumour necrosis factor, and transforming growth factor $\beta$ are all synthesised by chondrocytes. ${ }^{51-54}$ Thus there may be intricate interactions between chondrocytes and locally produced agonists and antagonists that operate by autocrine/paracrine mechanisms.

We are grateful to Dr Jansen $e$ al for the gift of IGF-I cDNA and to the National Institute of Diabetes and Digestive and Kidney to the National Institute of Diabetes and Digestive and Kidney
Diseases for the IGF-I antibody. This work was supported by the Diseases for the IGF-I antibody. This
Arthritis and Rheumatism Council.

1 Muir H. Current and future trends in articular cartilage research in osteoarthritis. In: Kuettner K, ed. Articular cartilage biochemistry. New York: Raven, 1986; 423-41.
costich

2 Mankin H J, Brandt K D, Shulman L E. Workshop on etiopathogenesis of osteoarthritis. $\mathcal{f}$ Rheumatol 1986; 13: $1126-60$.

3 Froesch E R, Schmid C, Schwander J, Zapf J. Actions of insulin-like growth factors. Annu Rev Physiol 1985; 47 443-67.

4 Rinderknecht E, Humbel R E. The amino acid sequence of human insulin-like growth factor $I$ and its structural homology with proinsulin. 7 Biol Chem 1978; 253: 2769-76.

5 Rinderknecht E, Humbel R E. Primary structure of huma insulin-like growth factor II. FEBS Lett 1978; 89: 283-6.

6 Jansen M, van Schaik F M A, Ricker A T, et al. Sequence of cDNA encoding human insulin-like growth factor I precursor. Nature 1983; 306: 609-11.

7 Rotwein P. Two insulin-like growth factor I messenge RNAs are expressed in human liver. Proc Natl Acad Sci USA 1986; 83: 77-81.

8 D'Ercole A J. Somatomedins/insulin-like growth factors and fetal growth. F Dev Physiol 1987; 9: 481-495.

9 Daughaday W H, Rotwein P. Insulin-like growth factors and II. Peptide, messenger ribonucleic acid and gene structures, serum, and tissue concentrations. Endocr Res 1989; 10: 68-91

10 Schoenle E, Zapf J, Humbel R E, Froesch E R. Insulin-like growth factor I stimulates growth in hypophysectomized rats. Nature 1982; 296: 252-3.

11 Guenther H L, Hannelore E, Guenther E, Froesch E R, Fleisch $H$. Effect of insulin-like growth factor on collagen and glycosaminoglycan synthesis by rabbit articular and glycosaminoglycan synthesis by rabbit articu
chondrocytes in culture. Experientia 1982; 38: 979-81.

12 McQuillan D J, Handley C J, Campbell M A, Bolis S, Milway V E, Herington A C. Stimulation of proteoglycan biosynthesis by serum and insulin-like growth factor-I in cultured bovine articular cartilage. Biochem $\mathcal{F} 1986 ; 240$ 423-30.

13 Watanabe N, Rosenfeld R G, Hintz R L, Dollar L A, Smith $R$ L. Characterization of a specific insulin-like growth factor-I/somatomedin-C receptor on high density, primary monolayer cultures of bovine articular chondrocytes: regulation of receptor concentration by somatomedin, insulin and growth hormone. $\mathcal{F}$ Endocrinol 1985; 107: 275-83.

14 Jansen J, van Buul-Offers S C, Hoogerbrugge C M, de Poorter $T$ L, Corvol $M T$, Van den Brande $J$ L. Characterization of specific insulin-like growth factor (IGF)-I and IGF-II receptors on cultured rabbit articular chondrocyte membranes. $\mathcal{F}$ Endocrinol 1989; 120: 245-9.

15 Daughaday W H, Parker K A, Borowsky S, Trivedi B, Kapadia M. Measurement of somatomedin-related peptides in fetal, neonatal, and maternal rat serum by insulin-like growth factor (IGF) I radioimmunoassay, IGF II radioreceptor assay (RRA) and multiplication-stimulating activity RRA after acid-ethanol extraction. Endocrinolog 1982; 110: 575-81.

16 D'Ercole A J, Hill D J, Strain A J, Underwood L E. Tissue and plasma somatomedin-C/insulin-like growth factor (Sm-C/IGF-I) concentrations in the human fetus during the first half of gestation. Pediatr Res 1986; 20: 253-5.

17 D'Ercole A J, Stiles A D, Underwood L E. Tissue concen trations of somatomedin $\mathrm{C}$ : further evidence for multiple sites of synthesis and parrine or autocrine mechanisms action. Proc Natl Acad Sci USA 1984; 81: 935-9.

18 Lund P K, Moats-Staats B M, Hynes M A, et al. Somatomedin $\mathrm{C} /$ insulin-like growth factor-I and insulin-like growth facto II mRNAs in rat fetal and adult tissues. F Biol Chem 1986;
261: 14539-44.

19 Han V K M, D'Ercole A J, Lund P K. Cellular localization of somatomedin (insulin-like growth factor) messenger RNA in the human fetus. Science 1987; 236: 193-7.

20 Hynes M A, Van Wyk J J, Brooks P J, D'Ercole A J, Jansen M, Lund P K. Growth hormone dependence of somatomedin-C/insulin-like growth factor-I and insulin-like medin-C/insulin-like growth factor-I and insulin-like growth factor II messeng

21 D'Ercole A J, Applewhite-G T, Underwood L E. Evidence that somatomedin is synthesized by multiple tissues in the fetus. Dev Biol 1980; 75: 315-28. 
22 Canalis E, McCarthy T, Centrella M. Isolation and characterization of insulin-like growth factor I (somatomedin-C) from cultures of fetal rat calvariae. Endocrinology 1988; 122: rom 22 .

23 Clemmons D R, Underwood J, Van Wyk J. Hormonal control of immunoreactive somatomedin production by

cultured human fibroblasts. F Clin Invest 1981; 67: 10-19.
24 Mohan S, Wergedal J, Taylor A, Baylink D. Human
osteoblast like cells produce IGF-I and IGF-II in culture. osteoblast like cells produce IGF-I and IGF-II in culture. Clin Res 1988; 36: 156

25 Han V K M, Lund P K, Lee D C, D'Ercole A J. Expression of somatomedin/insulin-like growth factor messenger ribonucleic acids in the human fetus: identification characterisation, and tissue distribution. $\mathcal{F}$ Clin Endocrino Metab 1988; 66: 422-9.

26 Maniatis T, Fritsch E F, Shambrook J. Molecular cloning: a laboratory manual. New York: Cold Spring Harbor, 1982.

27 Cox K H, DeLeon D V, Angerer L M, Angerer R C. Detection of mRNAs in sea urchin embryos by in situ Detection of mRNAs in sea urchin embryos by in situ
hybridisation using asymmetric RNA probes. Dev Biol hybridisation using

28 Brahic M, Haase A T. Detection of viral sequences of low reiteration frequency by in situ hybridisation. Proc Nat Acad Sci USA 1978; 75: 6125-9.

29 Funa K, Steinholtz L, Nou E, Bergh J. Increased expression of $\mathrm{N}$-myc in human small cell lung cancer biopsies predicts lack of response to chemotherapy and poor prognosis. $A m \mathcal{J}$ Clin Pathol 1987; 88: 216-20.

30 Tourtellotte W W, Verity A N, Schmid P, Martinez S, Shapshak P. Covalent binding of formalin fixed paraffin embedded brain tissue sections to glass slides suitable for in situ hybridisation. $\mathcal{F}$ Virol Methods 1987; 15: 87-99.

31 Furlanetto R W, Underwood L E, Van Wyk J J, D'Ercole A J. Estimation of somatomedin-C levels in normals and p J. Estimation of somatomedin-C levels in normals and patients with pituitary diseas
Invest 1977; 60: 648-57.

32 Chatelain P G, Van Wyk J J, Copeland K C, Blethen S L, Underwood $L$ E. Effect of in vitro action of serum proteases or exposure to acid on measurable immunoreactive somatomedin-C in serum. F Clin Endocrinol Metab 1983; 56: 376-82.

33 Meachim G, Stockwell R A. Adult articular cartilage. 2nd ed. London: Pitman Medical, 1979.

34 Mankin H J, Dorfman H, Lippiello L, Zarins A, Biochemical and metabolic abnormalities in articular cartilage from osteo-arthritic human hips. F Bone foint Surg [Am] 1971; 53: 523-37

35 Eyre D R, McDevitt C A, Billingham M E J, Muir $\mathbf{H}$. Biosynthesis of collagen and other matrix proteins by articular cartilage in experimental osteoarthrosis. Biochem $\mathcal{f}$ articular cartilage in

36 Ryu J, Treadwell B V, Mankin $\mathrm{H}$ J. Biochemical and metabolic abnormalities in normal and osteoarthritic human articular cartilage. Arthritis Rheum 1984; 27: 49-57.

37 Salmon W D, Daughaday W H. A hormonally controlled serum factor which stimulates sulfate incorporation by cartilage in vitro. $\mathcal{F}$ Lab Clin Med 1957; 49: 825-36.

38 Luyten F P, Hascall V C, Nissley S P, Morales T I, Reddi A H. Insulin-like growth factors maintain steady-state metabolism of proteoglycans in bovine articular cartilage explants. Arch Biochem Biophys 1988; 224: 206-23.
39 Tyler J A. Insulin-like growth factor I can decrease degradation and promote synthesis of proteoglycan in cartilage exposed to cytokines. Biochem 7 1989; 260: 543-8.

40 Schalkwijk J, Joosten L A B, van den Berg W B, van Wyk J J, van de Putte L B A. Insulin-like growth factor $\mathrm{J} J$, van de Putte L B A. Insulin-like growth factor
stimulation of chondrocyte proteoglycan synthesis by stimulation of chondrocyte proteoglycan synthesis
human synovial fluid. Arthritis Rheum 1989; 32: 66-71

41 Trippel S B, Corvol M T, Dumontier M F, Rappaport R, Hung $\mathrm{H} \mathrm{H}$, Mankin H J. Effect of somatomedin-C/insulin like growth factor I and growth hormone on cultured growth plate and articular chondrocytes. Pediatr Res 1989 ;
25: 76-82.

42 Vetter U, Helbing G, Heit W, Pirsig W, Sterzig K, Heinze E. Clonal proliferation and cell density of chondrocytes isolated from human fetal epiphyseal, human adult articular and nasal septal cartilage. Influence of hormones and growth factors. Growth 1985; 49: 229-45.

43 Froger-Gaillard B, Hossenlopp $P$, Adolphe $M$, Binoux $M$ Production of insulin-like growth factors and their binding proteins by rabbit articular chondrocytes: relationships proteins by rabbit articular chondrocytes: relationships
with cell multiplication. Endocrinology 1989; 124: 2365with cell 2372 .

44 Wood D D, Ihrie E J, Dinarello C A, Cohen P L. Isolation of interleukin-I like factor from human joint effusions. Arthritis Rheum 1983; 26: 975-83.

45 di Giovine F S, Meager A, Poole S, Duff G W. The presence of tumour necrosis factor alpha in synovial fluid from patients with rheumatic diseases. Calcif Tissue Int 1988; 42 (suppl): 158.

46 Pelletier J P, Martel-Pelletier J. Evidence for the involvement of interleukin 1 in human osteoarthritic cartilage degradation: protective effect of NSAID 7 Rheumatol 1989; 16 : 19-27.

47 Arend W P, Dayer J-M. Cytokines and cytokine inhibitors or antagonists in rheumatoid arthritis. Arthritis Rheum 1990 33: 305-15.

48 Nilsson A, Isgaard J, Lindahl A, Dahlström A, Skottner A, Isaksson O G P. Regulation by growth hormone of number of chondrocytes containing IGF-I in rat growth plate. Science 1986; 233: 571-4

49 Nilsson A, Carlsson B, Isgaard J, Isaksson O, Rymo L. Regulation by GH of insulin-like growth factor-I mRNA expression in rat epiphyseal growth plate as studied with in situ hybridisation. $\mathcal{f}$ Endocrinol. In press.

50 Burch W M, Weir S, Van Wyk J J. Embryonic chick cartilage produces its own somatomedin-like peptide to stimulate cartilage growth in vitro. Endocrinology 1986; 119: 1370-6.

51 Ollivierre F, Gubler U, Towle C A. Expression of IL-1 genes in human and bovine chondrocytes: a mechanism for autocrine control of cartilage matrix degradation. Biochem autocrine control of cartilage matrix deg
Biophys Res Commun 1986; 141: 904-11.

52 Shinmei M, Masuda K, Kikuchi T, Shimomura Y. The role of cytokines in chondrocyte-mediated cartilage degradation. f Rheumatol 1989; 16: 32-4.

53 Guerne P A, Carson D A, Lotz M. IL-6 production by human articular chondrocytes: modulation of its synthesis by cytokines, growth factors and hormones in vitro. f Immunol 1990; 144: 499-505.

54 Morales T I, Joyce M E, Sobel M E, Roberts A B. Autocrine production of TGF- $\beta$ by calf articular cartilage. Trans Ortho Res Soc 1990; 15: 109 . 